\title{
Os banquetes do Yaokwa: potencialidades e limites do cinema e do património entre os Enawenê-nawê
}

\author{
Rodrigo Lacerda ${ }^{1}$ \\ Doutor pela Universidade Nova de Lisboa, Lisboa, Portugal \\ e Instituto Universitário de Lisboa, Lisboa, Portugal \\ rodrigofernandes@fcsh.unl.pt
}

Resumo $O$ artigo examina a utilização do cinema em processos de patrimonialização não institucional e institucional do ritual Yaokwa do povo Enawenê-nawê em dois momentos históricos diferentes, recorrendo a depoimentos de cineastas e antropólogos indigenistas, à análise filmica e a bibliografia ameríndia. As obras foram produzidas pelo projeto Vídeo nas Aldeias que, desde os anos 1980, desenvolve um trabalho colaborativo com comunidades indígenas na área do audiovisual. O primeiro documentário foi realizado num contexto de reflexão interna sobre a relação a estabelecer com a sociedade colonial. O segundo filme foi produzido quinze anos depois como parte do processo de patrimonialização institucional do ritualYaokwa que tinha como objetivo alertar para os desafios ambientais que vários empreendimentos capitalistas colocavam à manutenção do modo de vida dos Enawenê-nawê.

Palavras-chave: Enawenê-nawê.Yaokwa. Património. Cinema indígena.Vídeo nas Aldeias.

Os Enawenê-nawêt vivem no Vale do Rio Juruena, afluente do rio Tapajós, no noroeste do estado de Mato Grosso, e falam uma língua da família Arawak-Maipure.

1 Investigador do Centro em Rede de Investigação em Antropologia, Portugal. Pesquisa financiada pela FCT PD/ BD/52265/2013 e UID/ANT/04038/2013.

2 A autodenominação Enawenê-nawê também já foi grafada como Enauene-Naue, Enauenê-Nauê, Enawenê-Nawê e Enawene Nawe. No sentido de simplificar a leitura do artigo e porque "nawê" significa "povo", a partir deste momento passo a utilizar a expressão reduzida Enawenê. 
Atualmente, habitam numa única aldeia, com uma população estimada, em 2014, de 737 indivíduos, ${ }^{3}$ localizada na Terra Indígena (TI) Enawenê-nawê. A TI foi demarcada em 1996 e possui uma área de 742.088 hectares.

A aldeia é constituída por malocas dispostas em círculo, uma casa (hati $)^{4}$ de formato cônico onde são armazenados os instrumentos musicais e uma praça central onde uma parte significativa dos rituais da comunidade decorre. Os Enawenê subdividem-se em nove grupos ou clãs denominados yaokwa - termo polissémico e central para este povo que também denomina a estação ritual mais prolongada. O Yaokwa é um ritual extremamente complexo que dura sete meses e decorre durante o período de seca. É destinado a manter a ordem cósmica e social através da satisfação dos espíritos Yakairiti, seres condenados a uma fome insaciável, de modo a que estes não causem a doença ou a morte dos humanos. A cada dois anos, os clãs dividem-se em Harikare e Yaokwa. Os primeiros são os anfitriões e permanecem na aldeia com as mulheres a preparar o sal vegetal, outros alimentos, a roça, a lenha e a limpar o pátio e os caminhos. Os Yaokwa são os pescadores que durante dois meses assentam nos rios e constroem barragens intricadas para recolher os peixes que oferecem aos Yakairiti no regresso à aldeia, na qual cantam e dançam no pátio. Atualmente, o ritual Yaokwa encontra-se ameaçado devido ao impacto ambiental, entre outros, da exploração madeireira intensiva, poluição da água, mineração e construção de barragens.

O artigo examina a produção de dois documentários sobre o ritual Yaokwa - Yâkwá, O Banquete dos Espíritos (Valadão, 1995) e Yaõkwá, Um Patrimônio Ameaçado (Campoli; Carelli, 2009) - e como estes representam dois processos distintos de patrimonialização, que revelam as potencialidades e os limites das políticas de "cultura com aspas" (Cunha, 2009). Os dados do artigo decorrem da minha pesquisa de doutorado sobre as relações entre cinema indígena e património institucional e não institucional com um especial enfoque na produção colaborativa do projeto Vídeo nas Aldeias (VNA). O trabalho de campo incluiu sete meses de cooperação com o VNA na organização, produção e montagem de oficinas de realização para cineastas indígenas e filmes indígenas durante os quais levei a cabo entrevistas semi-estruturadas com os colaboradores atuais e antigos do projeto. Os contributos para a análise do primeiro filme advêm principalmente das entrevistas com Vincent Carelli, companheiro de Vírigina Valadão, cinegrafista, fundador e ainda atual coordenador do VNA, Rita Carelli, filha daqueles que os acompanhou nas viagens durante a infância e adolescência, Altair Paixão, cinegrafista, e Tutu Nunes, montador. Em relação ao documentário mais recente, as principais entrevistas decorreram comVincent Carelli, Altair Paixão, Tiago Campos Tôrres, operador de câmara, e Leonardo

3 Disponível em: https://pib.socioambiental.org/pt/Povo:Enawen\%C3\%AA-naw\%C3\%AA, consultado a 30 de outubro de 2018.

4 Também denominada como casa dos clãs (Silva, 1998), casa dos yaõkwa (Jakubaszko, 2003) e casa das flautas (Santos, 2006).

5 Atualmente, existem nove clãs: aweresese, kairole, kawekwalise, anihiare, mairoete, kawinailiri, kaholase, lolahese, maolokori. 
Sette, montador. Estes dados foram complementados com uma análise fina das obras filmicas acompanhada de bibliografia etnográfica sobre os Enawenê e do artigo escrito porVírgina Valadão (1999) sobre o processo de realização do primeiro filme. Apesar dos depoimentos dos cineastas e alguma bibliografia incluírem informação sobre a perspetiva política e cosmológica dos Enawenê a propósito destes empreendimentos, seria importante aprofundar, no futuro, este ângulo.

Figura 1 - Barragem Enawenê

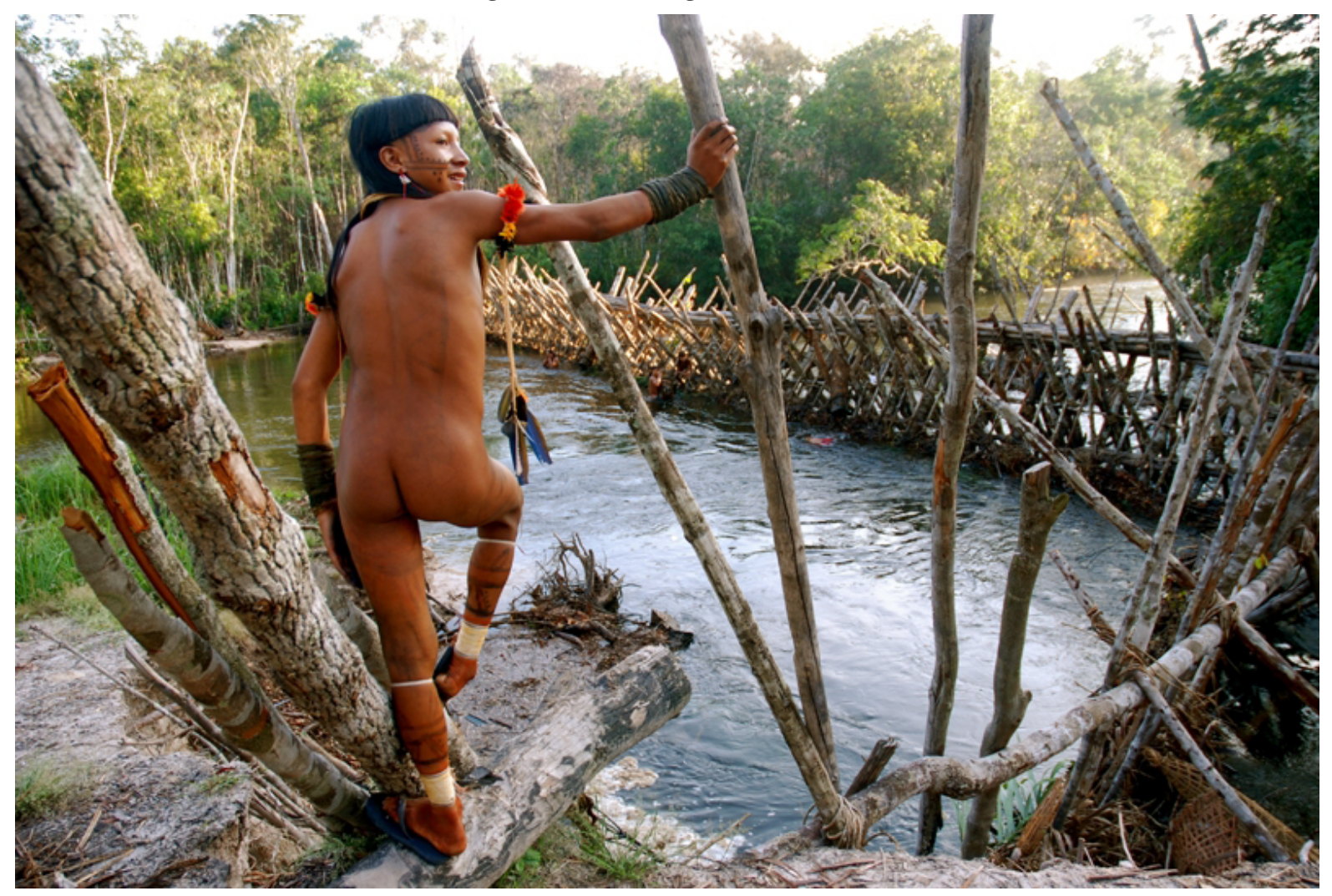

Fonte: Fotografia de Vincent Carelli.

\section{O banquete visual do Vídeo nas Aldeias}

Segundo relatos dos Enawenê, a sua estrutura social, cultural e organizacional é derivada de uma história complexa em que povos de várias origens e com línguas diferentes se uniram numa única aldeia devido à expansão da fronteira colonial, ataques de inimigos, doenças e mortes por feitiços. ${ }^{6}$ Apesar destes contatos indiretos com a sociedade colonial, ${ }^{7}$ as primeiras notícias oficiais no mundo ocidental datam de 1973 quando uma

6 Este exemplo é paradigmático da conceção cada vez mais comprovada em termos empíricos que os coletivos indígenas possuem uma história rica de contatos e trocas em rede antes da chegada dos colonos e que aqueles nunca foram estruturas isoladas.

7 Certos elementos mitológicos indiciam que, no passado, alguns Enawenê foram escravizados por colonos (ver, por exemplo, Almeida, 2015). 
aeronave da Missão Jesuíta Anchieta avistou a aldeia. ${ }^{8}$ No ano seguinte, foram estabelecidos contatos diretos entre os Enawenê e a Missão e, três anos depois, o missionário espanhol Irmão Vincente Cañas passou a viver na aldeia. O missionário, que é, até hoje, recordado com carinho pelos indígenas, manteve-os relativamente isolados, apoiando-os nas áreas da saúde e da diplomacia com a sociedade colonial. As enfermeiras tinham de viver nas casas dos indígenas e aprender a língua e os bens industrializados foram reduzidos ao mínimo, com exceção de instrumentos de ferro e anzóis que foram a contrapartida exigida pelos Enawenê para aceitarem o contacto com a Missão. Esta abordagem impediu o surgimento de epidemias e preservou o seu modo de vida tradicional. Em 1987, Cañas foi assassinado por latifundiários. Após este trágico incidente, a ONG Operação Amazônia Nativa (Opan) ${ }^{9}$ assumiu a função de assistência e iniciou um processo gradual de abertura ao exterior de modo a prepará-los para um futuro de relações mais complexas com a sociedade colonial.

Como parte deste processo de abertura, o projetoVídeo nas Aldeias (VNA) começou a trabalhar com os Enawenê em 1987 (Valadão, 1999). OVNA foi criado em 1986 como parte da ONG Centro de Trabalho Indigenista (CTI) com o objetivo de apoiar a luta dos povos indígenas no fortalecimento das suas culturas e identidades através do recurso ao audiovisual. A partir do ano 2000, o VNA tornou-se numa ONG independente. A sua história pode ser dividida em duas fases. Na primeira década, o projeto colaborava com comunidades indígenas e respondia às suas demandas, mas eram os não indígenas que assinavam a realização dos filmes. Nesta fase, os principais indigenistas realizadores foram Vincent Carelli, que ainda hoje coordena o projeto;Virgínia Valadão, antropóloga e segunda mulher de Carelli até à sua morte repentina em 1998; Altair Paixão, jornalista e documentarista; Tutu Nunes, montador; e outras antropólogas que não trabalharam com os Enawenê, como Dominique Gallois e Regina Müller. Os principais objetivos da utilização do vídeo pelo projeto eram estimular a reflexão interna das comunidades sobre a sua situação e futuro cultural, estabelecer uma rede de troca de imagens e experiências entre aldeias e povos no sentido de fomentar um movimento político panindígena (Ramos, 1998) e fornecer instrumentos de "talk back" (Ginsburg, 1993) para a sociedade colonial. Nesta fase, os povos autóctones estavam principalmente interessados nas filmagens em bruto, nomeadamente de cantos e performances, e os documentários editados eram direcionados ao mundo ocidental e à promoção do projeto no sentido de

8 Existem, porém, registros históricos pontuais e esparsos sobre contatos anteriores (Rodgers, 2014). Além disso, a aldeia fora avistada em 1968 num sobrevoo da FUNAI, mas a informação não foi comunicada porque os responsáveis pensavam que se encontrava dentro do Parque Indígena Aripuanã que estavam a demarcar (Almeida, 2015).

9 A Opan foi a primeira organização indigenista fundada no Brasil, em 1969. As principais formas de atuação da ONG são a proteção das terras indígenas por meio de programas de vigilância, monitoramento, gestão territorial, fortalecimento das organizações indígenas, formação política, fomento às cadeias de produtos da sociobiodiversidade, soberania alimentar, geração de renda e desenvolvimento sustentável. Disponível em: http://amazonianativa.org.br/Institucional.html, consultado a 30 de outubro de 2018. 
captar o sempre escasso financiamento. Sempre que possível, o projeto deixava câmaras nas aldeias e promovia uma transmissão não sistematizada de conhecimento no sentido de os indígenas mais interessados prosseguirem o trabalho na sua ausência. ${ }^{10} \mathrm{~A}$ partir de 1997, o VNA começou a organizar oficinas de formação de realizadores indígenas nas aldeias, apesar de a produção continuar a efetuar-se maioritariamente com equipas mistas num contexto de diálogo intercultural.

A equipa do VNA chegou à aldeia Enawenê em 1987 através da mediação de Altair Paixão que, na altura, namorava uma colaboradora da Opan. Naquela época, os Enawenê eram célebres no mundo da antropologia porque tinham sido resguardados da sociedade nacional e possuíam algumas idiossincrasias, como não consumirem carne de caça e água. ${ }^{11}$ Segundo Paixão, ele eVirgínia Valadão foram os "décimos quintos brancos" a entrar na aldeia e a experiência foi impactante: "Aí começou o fascínio todo, todas as histórias assim. É o grupo que a Virgínia pirava, eu pirava, nossa que é isso? Que planeta é esse?"12

Valadão foi o único elemento do VNA que esteve presente em todas as viagens e foi uma figura essencial para o desenvolvimento do projeto devido à sua personalidade particular. Na primeira viagem, os Enawenê casaram Valadão com um dos velhos pajés da aldeia, Ataina, e quando Carelli os visitou, casaram-no com a mulher daquele. Por fim, quando os dois levaram os seus filhos, Rita e Pedro, estes foram acolhidos como filhos de Ataina e sua mulher. Segundo Rita, "[...] o Ataina era uma coisa linda. Todo o dia de madrugada, quando começava a esfriar, ele vinha botar brasinha em baixo da minha rede, da rede da minha mãe. Eles tinham realmente um carinho, uma relação muito forte. Era uma pessoa muito especial.",13

SegundoValadão (1999, p. 165), os Enawenê estavam “ansiosos por conhecer o mundo em volta" e só tinham obtido algumas informações a partir da Opan (essencialmente sobre os seus direitos fundiários e os perigos de doenças derivados do contato com os não indígenas) e de expedições esporádicas aos povos vizinhos com quem trocavam peixe por bens ocidentais, como panelas e roupas. Neste contexto, o VNA considerava que

[e]ra necessário dar aos índios a oportunidade de ampliar o conhecimento e experiência das coisas e do comportamento dos brancos, contribuindo com a compreensão gradativa da diversidade de intenções e de relações possíveis com diversas categorias de "outros", parâmetros indispensáveis para que um grupo indígena isolado possa construir e controlar, em ritmo próprio, seu espaço de relacionamento no mundo dos brancos. (Valadão, 1999, p. 167).

10 De facto, alguns cineastas indígenas hoje em dia consagrados, como o Xavante Divino Tserewahú, começaram a filmar no início da década de 1990 através desta transmissão não sistematizada de conhecimentos.

11 Em alternativa, os Enawenê consomem bebidas processadas de mandioca e de milho e hidromel.

12 Entrevista a Altair Paixão, 8 de outubro de 2015.

13 Entrevista a Rita Carelli, 26 de abril de 2016. 
O curta Antropofagia visual (Carelli, 1995) sintetiza este processo intercalando várias experiências dos Enawenê com a câmara de filmar e algumas cenas de Valadão e Carelli na ilha de edição a explicarem e a refletirem sobre este trabalho. Como Carelli explica no início desta obra:

A gente já levou o vídeo para várias comunidades indígenas. Mas, embora o entusiasmo seja sempre o mesmo, as reações são diferenciadas evidentemente. Tem povos muito curiosos em relação aos outros. Tem povos que preferem se ver. Tem povos mais reservados. E tem povos muito extrovertidos. Os Enawenê-nawê são inéditos! Eles são os mais extrovertidos que eu jamais tenho encontrado. Eles são os mais exibidos que eu conheço, sem dúvida nenhuma.

Como se torna evidente no filme, os Enawenê apoderaram-se da linguagem cinematográfica rapidamente e propuseram várias ideias, nomeadamente para se divertirem quando assistiam às filmagens no pátio central. Por exemplo, uma sequência com cortes rápidos mostra os homens a retirarem o estojo peniano e a exibirem o pénis ostensivamente para a câmara, por vezes também as nádegas e o ânus, ou a simularem atos sexuais. Todos estes episódios são acompanhados de muito riso. Valadão elucida em off: "Este gesto que acabaram de ver não tem a conotação agressiva que teria em nossa sociedade. [...] Sexo não é pecado para os adultos, nem mistério para as crianças."

Num primeiro momento, o VNA projetou no pátio da aldeia filmagens de rituais de diversas comunidades indígenas que faziam parte do arquivo do CTI com o objetivo dos Enawenê conhecerem outros povos. ${ }^{14}$ Além disso, o VNA estava preocupado com a demora do processo de demarcação da TI e exibiu vídeos relativos a esta temática, como, por exemplo, sobre a invasão de garimpeiros nos territórios Yanomami e Nambikwara. As imagens fomentaram um espaço coletivo de reflexão que, segundo o indigenista Fausto Campoli (Valadão, 1999, p. 169), foi fundamental para a consciencialização da importância de não ficar dependente da ação tutelar da FUNAI e desenvolver estratégias de autodeterminação e autodemarcação.

Figuras 2 e 3 - Enawenê assistindo a filmagens no pátio central da aldeia

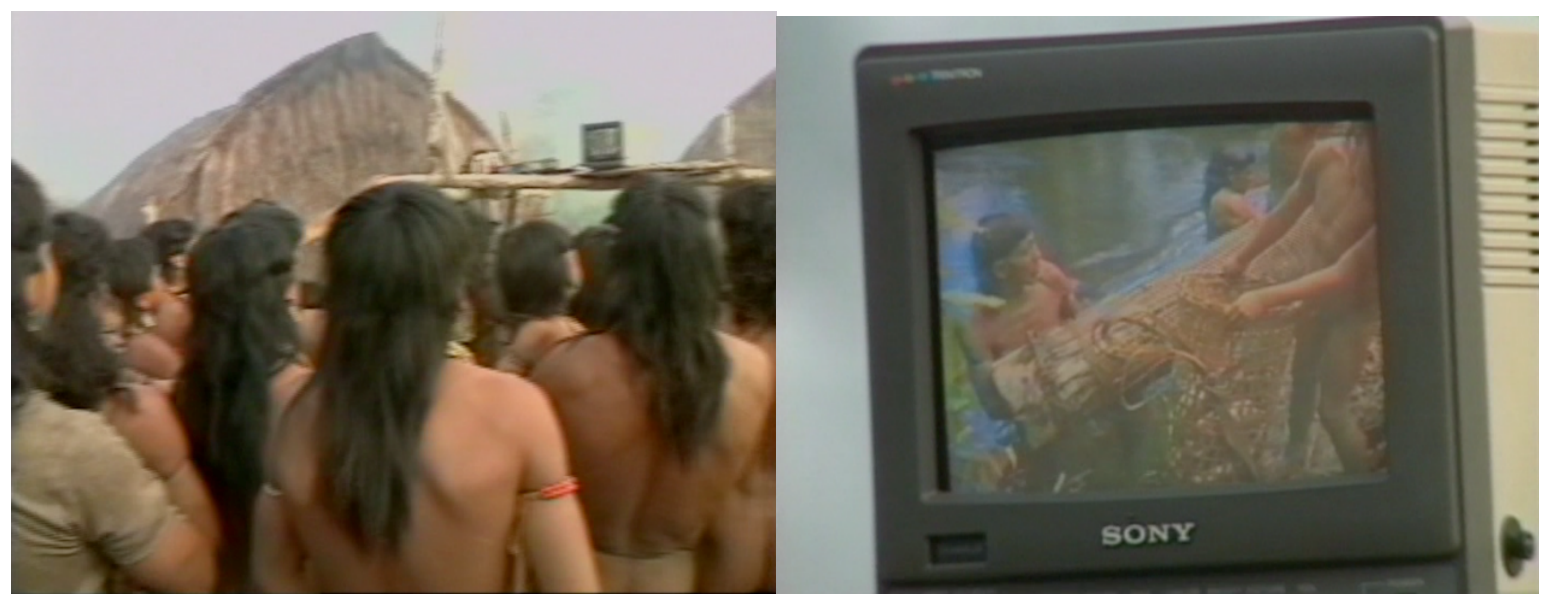

Fonte: Fotogramas de Antropofagia Visual.

14 Em relação a uma experiência similar com os Wajãpi, ver Gallois e Carelli, 1992. 
Progressivamente, o VNA também começou a exibir filmes de ficção de temática indígena, como Dances with wolves (1990) e Geromino (1993). Quando assistiram a Avaeté, semente da vingança (1984), de Zelito Viana, os Enawenê não perceberam como um dos atores indígenas, que eles conheciam e estava vivo, podia ter morrido no filme.A partir da discussão desta situação, eles compreenderam a diferença entre documentário e ficção ${ }^{15}$ e decidiram realizar uma obra ficcional sobre dois posseiros que tinham assassinado por terem invadido o seu território. Esta reconstituição histórica é incluída na parte final do filme Antropofagia Visual que é constituído por um making of, durante o qual demonstram que os não indígenas começaram por orientar a realização, mas foram rapidamente suplantados pela ação dos Enawenê, e o curta-metragem resultante desta experiência em que os atores não indígenas representam os posseiros que são mortos com flechas e exibidos de um modo relativamente gráfico.

O filme foi e é controverso. Na altura, um académico da New York University chegou a pedir a Carelli para o não mostrar ao mundo ocidental porque iria destruir a reputação dele e doVNA ${ }^{16}$ e, de facto, apesar de fazer parte do catálogo oficial da ONG, não costuma ser exibido em mostras de cinema indígena. $O$ filme é incómodo porque foge à expectativa ocidental de ver os indígenas representados como vítimas. Enquanto a História e o cinema nacional e hegemónico não têm problemas (e até preferem) celebrar as vitórias (isto é, as derrotas dos outros), há a expectativa dos "modernos" que a História e o cinema dos subalternos se baseiem na vitimização. De certa maneira, parafraseando a famosa frase de Karl Marx, é preciso ser derrotado duas vezes para se ser respeitado enquanto subalterno: primeiro como tragédia, depois como cinema. Assim, num primeiro momento de Antropofagia visual, os Enawenê, povo recém-“contatado", parecem se adequar ao imaginário romântico do índio inocente. Mesmo as brincadeiras sexuais, apesar de poderem importunar alguns, são passíveis de serem interpretadas como jogos de crianças, uma categoria sob a qual os indígenas estiveram subjugados durante séculos, inclusive a nível legislativo. Contudo, a sequência final demonstra que eles não são nem inocentes, nem crianças. Mas, naquele momento, já convivemos vários minutos com os Enawenê e não os conseguimos conciliar com o imaginário oposto em que os indígenas são classificados como bárbaros e desumanos. No final do filme, o espetador está fora do diagrama esquemático que a modernidade desenhou para os indígenas: a inocência ou a barbárie. A obra obriga-nos a ir para além do mapa que tínhamos como seguro. Por outro lado, perante o visionamento dos filmes e contatos com as ONG, os Enawenê compreenderam que existiam muito mais não indígenas do que eles pensavam

15 Esta argumentação de Valadão não é totalmente convincente. Em cenas anteriores de Antropofagia visual, os Enawenê encenaram para a câmara um ataque dos Cinta Larga em que eles fingiram que estavam mortos. Ou seja, a noção de performatizar a morte já existia naquele povo e, por isso, a utilização deste dispositivo no cinema não devia ser de difícil transposição.

16 De certo modo, esta reação é paralela à que Marcel Griaule teve perante a primeira exibição do filme Les Maîtres Fous (1955) realizado pelo seu antigo orientando de doutoramento, Jean Rouch (Henley, 2010). 
e consideraram importante mostrarem, desconhecendo o esquema desenhado para eles pela modernidade, que também eram numerosos, fortes e, quando necessário, ferozes. ${ }^{17}$

Em 1990, os Enanewê e o VNA decidiram registrar o ritual Yaokwa de forma sistemática no formato profissional Betacam (anteriormente, já tinham capturado imagens em Super-VHS). Como o ritual dura setes meses, ele foi filmado ao longo de três anos (1990-1992). A escolha dos Enawenê tinha dois propósitos. Em primeiro lugar, a nível de registro interno, eles estavam preocupados com a iminente morte de cinco cantadores velhos que eram os únicos que sabiam tudo sobre o ritual (Valadão, 1999, p. 171). Nesse sentido, podemos considerar que este filme faz parte da tradição de utilização do cinema nas cruzadas de salvaguarda das culturas em desaparecimento que, nos anos 1970, Margaret Mead (2003 [1974], p. 3) ainda considerava ser uma das incumbências da antropologia (ver Brigard, 2003 [1974]; Durington; Ruby, 2011; Pinney, 2011). Progressivamente, esta abordagem começou a ser criticada por essencializar e reificar povos e culturas e ocultar as relações e fricções destes com a modernidade. Apesar da validade destas críticas para a maioria da produção audiovisual daquele período, a importância que o filme em análise ainda hoje tem para os Enawenê sublinha a relevância que estes registos podem adquirir, especialmente quando produzidos de um modo colaborativo, engajado e sensível.

Em segundo lugar, os Enawenê queriam mostrar aos "outros" o seu ritual mais importante e aquele em que eles se afirmavam como belos. De facto, quando o VNA explicou que o filme seria vendido e que o lucro seria investido na comunidade, os Enawenê inquiriam sobre o preço da obra e argumentaram que o seu trabalho deveria ter o valor mais elevado, seguido do dos Wajãpi, que apesar de inferiores a eles, também consideravam belos (Valadão, 1999, p. 175). É, contudo, importante sublinhar que, ao contrário das conceções ocidentais, nas cosmologias ameríndias, o belo não é inerente às coisas, mas é antes uma qualidade estético-ética de elementos materiais e intangíveis (como os nomes das pessoas) que consubstancia as relações sociais positivas, frequentemente através de rituais (Overing, 1991; Overing; Passes, 2000). Por exemplo, em relação aos Xikrin, Cesar Gordon (2011, p. 222) argumenta que

[...] o ritual é precisamente o contexto em que os Xikrin se mostram e se fazem belos (por isso também, por exemplo, é que eles preferem sempre ser fotografados em trajes rituais, pois é quando se sentem apropriadamente apresentáveis). [...] Os rituais são momentos em que a própria sociedade mebêngôkre mostra-se como deve ser: bela, correta, boa. (itálico no original).

De qualquer modo, também é relevante lembrar que a maioria das imagens projetadas pelo VNA eram referentes a rituais de outros povos e pode ter sido considerado pelos Enawenê que este é o elemento mais apropriado para comunicar com os "outros". Além disso, e essa é a razão por que a maior parte das filmagens iniciais do VNA foram sobre rituais (Gallois; Carelli, 1995), o cinema, mais do que outros dispositivos, como a escrita,

17 Os Wajãpi também demostram a mesma atitude em O espírito da TV (Carelli, 1990). 
consegue estabelecer uma comunicação não verbal através do registro de performances e estéticas socias (MacDougall, 1998; Henley, 2011).

Existem, contudo, limitações na transposição de um ritual, especialmente um tão complexo como o Yaokwa, para o formato de documentário: um ritual tende a ter uma duração muito superior à de um filme (pelo menos, no formato canónico), a compreender várias ações a decorrer em simultâneo, a envolver múltiplos personagens e a incluir repetições potencialmente entediantes para a audiência. Segundo Valadão (1999, p. 170), as filmagens foram constituídas por planos-sequência longos de cantos e performances de modo a servir de registro interno para os Enawenê e também como uma espécie de "diário de campo" para a antropóloga. Na fase de edição, estes momentos tiveram de ser reduzidos, tendo em conta uma audiência ocidental. Além disso, o filme evitou o foco num único ou num número reduzido de personagens, uma vez que o Yaokwa "[...] implica uma troca generalizada e constante que envolve todo o coletivo Enawenê" (Valadão, 1999, p. 163).

Ademais, certos rituais ou momentos destes são exclusivos de um segmento da comunidade e não podem ser vistos pelos restantes. Por exemplo, em Wapté Mnhõnõ, Iniciação do jovem Xavante (1999), do Xavante Divino Tserewahú, o cineasta explica para a câmara que a parte seguinte do ritual não pode ser observada pelas mulheres e, por isso, não foi incluída no filme. No caso dos Enawenê, as mulheres não podem entrar na casa das flautas e não podem estar presentes quando os instrumentos musicais são tocados no pátio central porque podem ser atacadas pelos Yakairiti. Contudo, eles consideraram que as imagens não capturavam os espíritos e que, portanto, podiam ser exibidas para todos. Mesmo assim, segundo Carelli, quando Valadão morreu subitamente, em 1998, os Enawenê comentaram que este incidente tinha ocorrido por ela ter visto muito Yaokwa.

Outra questão problemática para os povos indígenas é a fixação da imagem de uma pessoa que, posteriormente, tenha falecido. ${ }^{18}$ Como é transversal aos povos ameríndios, os objetos das pessoas que morrem, incluindo, por vezes, as próprias casas, são enterrados ou destruídos. A equipa do VNA expôs o problema à comunidade que considerou que as imagens podiam ser mostradas "aos de fora”, não indígenas e indígenas não Enawenê. Em relação à exibição dentro da comunidade, o assunto revelou-se mais complexo. Enquanto os parentes dos falecidos consideravam que as imagens deviam ser ocultadas, os outros desejavam vê-las. Segundo Valadão (1999, p. 173), a solução encontrada na altura foi não mostrar as filmagens dos mortos até que o espírito tivesse tempo para abandonar o mundo dos vivos e, após este período, ficava ao critério de cada um se queriam vê-las ou não. Não obstante, os ritos fúnebres passaram a incluir a queima de cassetes de vídeo que eram permitidas pelos outros por saberem que existiam cópias no arquivo doVNA. 
Figura 4 - Operador de câmara Enawenê Figura 5 - Instrumentos musicais a serem tocados no pátio da aldeia durante o Yaokwa

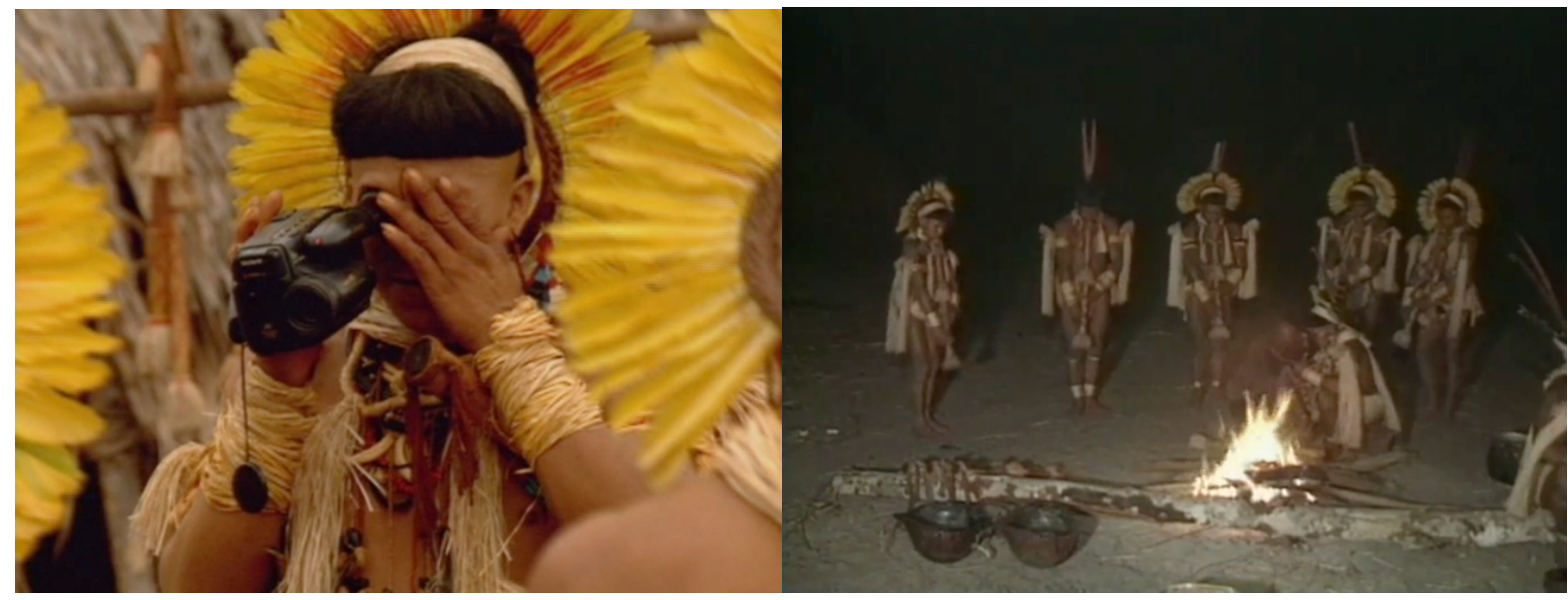

Fonte: Fotograma de Antropofagia visual.

Fonte: Fotograma de Yãkwá, o banquete dos espíritos.

À medida que o Yaokwa ia sendo gravado, oVNA mostrava as imagens aos indígenas que, pacientemente, traduziam e explicavam as falas e as performances. $\mathrm{O}$ envolvimento dos Enawenê levou a que estes participassem cada vez mais com sugestões e demandas. Além disso, tal como procediam com outros povos, a ONG deixou na aldeia equipamento de filmagem e de exibição no sentido dos Enawenê prosseguirem as filmagens na sua ausência. Apesar de ter sido designado um operador de câmara oficial, este material foi o primeiro bem ocidental de uso coletivo, uma vez que os barcos a motor eram propriedade da OPAN. Porém, o controlo daquele gerou disputas internas que levaram o VNA a retirá-lo temporariamente até os Enawenê chegarem a um acordo (Valadão, 1999, p. 172174). 19

Tendo em conta as questões acima mencionadas, o montador Tutu Nunes admite que talvez tenha sido o trabalho de edição mais difícil da sua vida. Além do exposto, Nunes deparou-se com imagens repetidas de anos diferentes que possuíam qualidades distintas. Por exemplo, um plano de um determinado ano poderia ser mais bonito em termos de luz, ângulo, performance ou qualidade técnica (o formato Betacam é melhor que o Super-VHS), mas não poderia ser montado em conjunto com planos de outros anos sobre a mesma etapa que poderiam ter outras qualidades (incluir determinado detalhe do ritual, câmara mais estável, etc.). Por esta razão, ainda mais do que noutros trabalhos, "a edição inteira foi permeada por jogar coisas no lixo que doíam”. ${ }^{20}$ Neste contexto, Valadão contribuiu com a sua experiência antropológica, mas também com um olhar único. Como Tutu Nunes explica:

O que ela trazia era um olhar muito pessoal sobre as coisas e o não abrir mão do prazer de assistir a uma coisa bonita e gostosa de se ver, entendeu? Ela queria que a coisa ficasse agradável, encantadora. Ela sacrificava informação com prazer. Era uma antropóloga que sacrificava informação em detrimento

19 Para uma situação similar entre os Kayapó, ver Turner, 2002.

20 Entrevista a Tutu Nunes, 25 de abril de 2016. 
de uma música. Ela acreditava que talvez uma música, uma dança, falassem muito mais sobre o povo do que uma explicação antropológica. Então, o que ela trazia era isso. Assim, essa proximidade das pessoas que ela trazia para o vídeo, também. Ela fazia as pessoas se aproximarem da câmara e revelar coisas. E contar coisas bem gostosas. Contar histórias de forma gostosa. Ela ficava amiga das pessoas, do povo, entendeu? A colaboração final para o vídeo... o resultado final que isso traz é incomensurável. (Entrevista a Tutu Nunes, 25 de abril de 2016)

Yãkwa, o banquete dos espíritos (Valadão, 1995) foi o documentário que resultou desta experiência. A estrutura narrativa é sequencial e foi construída através do entrelaçar das etapas do ritual com narrativas que explicam aquelas. No início, o filme descreve o mito de origem do povo Enawenê que saiu de dentro de uma pedra para o mundo atual e, a seguir, o trabalho divide-se em quatros partes: "O mundo fora da pedra", "A vingança de Dataware", "Harikare, o anfitrião dos espíritos" e "A menina mandioca". Nesse sentido, ao contrário da maioria da produção do VNA, podemos considerar que este trabalho é um filme etnográfico clássico e, de facto, a obra foi premiada em diversos festivais, nomeadamente na $20^{a}$ Reunião da Associação Brasileira de Antropologia (ABA), em 1996, com o Prémio Pierre Verger deVídeo Etnográfico. É, contudo, importante lembrar que o documentário foi realizado em colaboração com os Enawenê porque estes queriam utilizar a beleza do ritual Yaokwa enquanto estratégia de diplomacia com a sociedade colonial. Não obstante, tendo em conta o acima exposto, o trabalho mais político do VNA nesta fase pode ser encontrado no processo de produção que incluiu diversos visionamentos da autoimagem dos Enawenê e de outros povos, incluindo os ocidentais, que fomentou uma reflexão interna sobre a sua situação cultural e colonial e o devir.

\section{O banquete do capitalismo}

Apesar do apoio da OPAN e doVNA, a viragem do século trouxe desafios e ataques ao modo de vida dos Enawenê para os quais teria sido impossível prepará-los. O que se segue é uma descrição sintética de um processo longo e complexo. ${ }^{21}$

Em 2002, a empresa Maggi Energia deu início ao projeto Complexo Juruena, que consistia na construção de nove hidroelétricas pequenas (menos de 30 megawatt) ${ }^{22}$ e duas hidroelétricas grandes num percurso de 110 quilómetros do rio Juruena, a montante da TI dos Enawenê. No ano seguinte, o líder do consórcio, Blairo Maggi23 tornou-se

21 Para mais informação, ver Almeida (2011, 2015), Galvão (2016) e Nahum-Claudel (2018).

22 As pequenas hidroelétricas foram denominadas Cidezal, Parecis, Rondon, Telegráfica e Sapezal.

23 O líder do consórcio, Blairo Maggi, é um empresário de soja do Mato Grosso que os Enawenê conhecem desde 1998, quando, em conjunto com o seu pai, subornou aqueles com um barco a motor de modo a abrir uma estrada ilegal que atravessa a TI. Esta ação foi bloqueada pelo Ministério Público Federal. 
governador do estado do Mato Grosso, ${ }^{24}$ uma posição que lhe conferiu poder para acelerar o empreendimento, apesar de várias ações legislativas federais encetadas na primeira década deste século já limitarem os requisitos de licenciamento das barragens e promoverem o seu desenvolvimento. ${ }^{25}$

A primeira visita de consulta aos Enawenê ocorreu em 2003. Estes iniciaram um processo interno de discussão do projeto, incluindo sobre os impactos ambientais e se iam aceitar a indeminização proposta. Os indígenas pensavam que as hidrelétricas só avançariam com o seu aval, mas, em 2007, um grupo de pescadores avistou a construção da barragem Telegráfica. Perante esta situação, os Enawenê escreveram uma carta para o promotor público a exigir a paragem da construção para que pudessem discutir a questão internamente. Perante a continuação dos trabalhos e a ausência de resposta, em dezembro de 2007, todos os homens Enawenê atacaram a barragem Telegráfica. O plano tinha sido cuidadosamente preparado de modo a não originar fatalidades e uma escalada de retaliações. As comunicações de rádio foram prontamente desligadas para não alertar as autoridades e provocar um contra-ataque e os trabalhadores foram evacuados em ônibus.

Em 2008, os Enawenê, ao mesmo tempo que assumiam as suas responsabilidades no Yaokwa, continuaram a realizar reuniões com as diversas agências governamentais, empresas envolvidas e outros povos afetados (Nambikwara, Myky, Rikbaktsa e Paresi). Os encontros não outorgavam garantias para os Enawenê ao mesmo tempo que o número de barragens propostas aumentava e o dinheiro das contrapartidas demorava a chegar. Numa das reuniões foi inclusive proposto que, se os Enawenê permitissem os estudos de viabilidade económica de uma barragem no centro da sua TI, talvez conseguissem obter o território ancestral que há muito reclamavam, mas que, se não os autorizassem, eles nunca obteriam essa terra. Mesmo a boa notícia de que o promotor público tinha ordenado a suspensão da construção do Complexo, em abril de 2008, devido a lacunas nos processos de licenciamento ambiental, foi anulada quatro meses depois pelo ministro Gilmar Mendes, do Supremo Tribunal Federal e natural do Mato Grosso, porque o seu cancelamento "[...] representa grave risco de lesão à ordem, a economia e à saúde pública do estado" (citado em Galvão, 2016, p. 59).

Por fim, a 30 de março de 2009, os Enawenê aceitaram a compensação de 1,5 milhões de reais pelas oito hidrelétricas do Complexo de Juruena com a exigência de que uma contrapartida anual fosse negociada no futuro, uma vez que as barragens eram perpétuas e, portanto, o pagamento também devia ser permanente. Em 2012, o ressarcimento inicial

24 Até 31 de março de 2010. De 1 de fevereiro de 2011 a 12 de maio de 2016 foi senador do Mato Grosso. A partir desta data, tornou-se ministro de Estado da Agricultura, Pecuária e Abastecimento do Governo de Michel Temer.

25 No início do século XXI, os estudos de impacto ambiental foram dispensados para barragens com menos de 30 megawatts e, em 2007, o governo federal aprovou o Programa de Aceleração do Crescimento (PAC) que promoveu a exploração energética dos rios da Amazónia, nomeadamente através de benefícios fiscais e empréstimos subsidiados pelo Banco Nacional de Desenvolvimento Econômico e Social. 
acabou e, no final do Yaokwa, os Enawenê ocuparam a sexta barragem (as outras cinco já estavam em funcionamento), o que resultou numa reunião em Brasília na qual ficou decidido que aquele povo indígena passaria a auferir de um pagamento mensal de 20.000 reais. Como resume a antropóloga Chloe Nahum-Claudel, que trabalhou na aldeia durante parte deste processo:

The pattern has been set at this frontier; money is available while political participation is denied. The letters written by the Enawenê in 2006-2007 suggest that they began with the assumption that their position would be of importance to the government. Their actions in 2008-2009 suggest that they learned that indifference is the default position. Recognition must be coerced. (Nahum-Claudel, 2018, p. 251).

\section{Património: o banquete das "culturas"}

Com o objetivo que o reconhecimento nacional e internacional do modo de vida Enawenê permitisse fazer frente ao projeto das barragens, a OPAN recorreu a diversos instrumentos de "cultura com aspas" (Cunha, 2009) ${ }^{26}$ Para Manuela Carneiro da Cunha, as pessoas vivem simultaneamente em cultura (no sentido antropológico) e em "cultura com aspas", uma meta-linguagem, isto é, uma noção que fala sobre si própria, que pode ser utilizada enquanto recurso de afirmação de identidade, dignidade e poder em situações de contacto inter-étnico. Os dois regimes podem coexistir e até identificar os mesmos traços culturais, mas pertencem a universos de inteligibilidade distintos. É por esta razão que, por exemplo, certos grupos indígenas utilizam a palavra portuguesa "cultura" em discursos políticos proferidos na sua língua.

Um dos mecanismos mais importantes de "cultura com aspas" utilizados foi a candidatura do ritual Yaokwa a património cultural imaterial. Os proponentes foram o povo Enawenê (com três representantes de cada um dos nove clãs) e a Opan. Seguindo os trâmites institucionais de uma forma célere, o ritual Yaokwa foi registrado como Património Cultural Imaterial no Livro das Celebrações do Instituto do Patrimônio Histórico e Artístico Nacional (Iphan), em 2010, ${ }^{27}$ e incluído na Lista de Património Cultural Imaterial da Humanidade em Necessidade de Salvaguarda Urgente da Unesco, em 2011. ${ }^{28}$

Segundo Laurajane Smith (2006), o património institucional é um instrumento de governamentalidade que recorre às ciências sociais para produzir uma mentalidade, isto é,

26 Por exemplo, em 2008, a Opan organizou, em colaboração com a Survival International, a visita de um jornalista de The Sunday Times com o objetivo de denunciar a situação (Nahum-Claudel, 2018).

27 Disponível em: http://portal.iphan.gov.br/pagina/detalhes/74, consultado a 31 de outubro de 2018.

28 Disponível em: https://ich.unesco.org/en/USL/yaokwa-the-enawene-nawe-people-s-ritual-for-the-maintenance-of-social-and-cosmic-order-00521, consultado a 31 de outubro de 2018. 
um modo de pensar o mundo, nomeadamente as questões relacionadas com a identidade. Assim, num primeiro momento, o património foi constitutivo da (e foi constituído pela) identidade nacional. Porém, a autora propõe que estes instrumentos são frequentemente apropriados e subvertidos pelos subalternos, podendo-se argumentar que "[h]eritage thus becomes not only a tool of governance, but also a tool of opposition and subversion" (Smith, 2006, p. 52). De um modo semelhante, a antropóloga Sílvia Guimarães, que trabalhou em Brasília, entre 2006 e 2010, na Coordenação de Registro do Departamento de Patrimônio Imaterial do Iphan, ${ }^{29}$ sublinha que "[...] o que eu acho legal nessas políticas todas é que você vê as pessoas subvertendo, fazendo usos disso, isso é que eu acho que é importante". 30

Assim, o património, dentro do enquadramento institucional e enquanto processo cultural dinâmico e performático associado à memória, tem sido apropriado e repensado por comunidades indígenas para solidificar e constituir discursos e práticas de etnicidade que utilizam com fins políticos vários (por exemplo, reivindicações de direitos fundiários e de propriedade intelectual). Segundo esta perspetiva, Carelli argumenta que o património é principalmente interessante

[...] porque essa questão da invisibilidade dos índios na sociedade nacional é a questão de fundo! E eu acho que o caminho da cultura é o mais eficaz num processo de valorização do índio. Porque, se não, você fica no índio flechando guarda, enfim, enfrentando a Força Nacional, a Polícia Militar! E a arte - que seja vídeo, que seja pintura, que seja literatura, que seja o que for - é o melhor meio de educar, de atrair o interesse das pessoas, de seduzir as pessoas e interessar minimamente as pessoas pelos índios. (entrevista a Vincent Carelli, 16 de março de 2015).

A candidatura do património cultural imaterial requere a realização de dois registros audiovisuais (uma longa-metragem e um curta para apresentação na reunião do Conselho Consultivo do Patrimônio Cultural).Tendo em conta a experiência anterior, os Enawenê exigiram que aqueles fossem produzidos pelo VNA. O filme resultante, Yaõkwá, um patrimônio ameaçado (2009), é assinado por Carelli e Fausto Campoli, um dos principais interlocutores da Opan, colaborador do primeiro documentário sobre o Yaokwa e o único que compreendia a língua de um modo proficiente, tendo colaborado no registro de depoimentos e na tradução. ${ }^{31}$ A direção de fotografia é da responsabilidade de Paixão, Carelli e Tiago Campos Tôrres. O ritual foi filmado em 2009 em quatro etapas que totalizaram oitenta dias de trabalho.Além disso, respondendo às demandas da comunidade, o VNA entregou aos Enawenê uma câmara profissional, um data show, um gravador de DVD, um gerador, um acervo de filmes sobre outros povos indígenas e algum do material

29 Atualmente, Sílvia Guimarães é professora na Universidade de Brasília.

30 Entrevista a Sílvia Guimarães, 4 de junho de 2016.

31 As antropólogas Ana Paula Lima de Rodgers e Juliana de Almeida e o Enawenê Lolawenakwaene Kairole também participaram na tradução. 
filmado com eles quinze anos antes ${ }^{32}$ e realizou uma oficina de formação de cineastas indígenas. Devido a este envolvimento, o VNA teve que investir parte do orçamento da ONG no projeto.

A inflação ou malaise patrimonial (Choay, 2010 [1982]) e a febre do arquivo (Derrida, 1995) dos séculos XX e XXI foram acompanhadas por uma produção de filmes sobre património, frequentemente influenciados pelas tradições cinematográficas de pendor romântico sobre "culturas em desaparecimento"33 ou do filme etnográfico clássico. Contudo, os trabalhos dos cineastas indigenistas e indígenas do VNA sempre assumiram um carácter político revelando a complexidade das vidas indígenas e das suas relações múltiplas com a modernidade e recusando o olhar romântico dos "modernos". Nesse sentido, considerei importante perguntar a Carelli como se realiza um bom filme sobre património, isto é, como é possível subverter a expectativa tendencialmente essencialista e reificante do património. Após uma breve pausa, Carelli respondeu sinteticamente: "É descobrir, enfim, o que é que os índios estão a fim de fazer, né?” Contudo, como veremos, esta abordagem não é necessariamente fácil de realizar.

E o que é que os Enawenê estavam a fim de fazer? Acima de tudo, registrar os seus rituais que estavam em perigo de desaparecer. Como explica Carelli:

De repente aquele filme [Yãkwá, O Banquete dos Espíritos] que a gente tinha feito ficou uma referência, eu acho que fez sentido para eles. [...] Eu acho que eles sacaram a importância desse registro. E aí, quando a gente voltou, eles quiseram despejar tudo... [...] $\mathrm{O}$ que aconteceu nessa segunda vez, nesse reencontro, foi que eles resolveram contar a mitologia inteira. Não sei porquê, mas eles diziam “vem cá, senta aí, grava, que eu vou contar...” Então, tem horas de contação de mitologia, que não foi usada para o filme, porque nem conseguimos traduzir. Mas eles estavam desesperados, querendo contar as coisas! Eles chamavam, marcavam com a gente, então eles estavam nessa ânsia... (entrevista a Vincent Carelli, 18 de março de 2015)

Além do Yaokwa, os Enawenê também queriam registrar os outros três rituais anuais: Saloma, Kateoko e Lerohi. Como Carelli menciona, a quantidade de material filmado foi tão elevada que não foi possível traduzir tudo e o cineasta ainda almeja completar o trabalho e produzir um filme mais completo. Recentemente, o VNA obteve financiamento para digitalizar parte do seu imenso arquivo e a ONG iniciou um processo de "repatriação visual" (Edwards, 2011) das filmagens realizadas no século passado com os Enawenê, o que permitirá desenvolver outros projetos com este povo.

$\mathrm{O}$ diretor de fotografia Tiago Campos Tôrres considera que a visita aos Enawenê foi uma das suas experiências mais fascinantes ("assim um brinde que Vincent [Carelli] me deu”). ${ }^{34} \mathrm{O}$ cineasta chama a atenção, contudo, que “descobrir o que os índios estão

32 O que correspondeu a um investimento de cerca de 20 mil reais.

33 Alusão à série de documentários Disappearing World, realizada pela Granada Television entre 1970 e 1993.

34 Entrevista a Tiago Campos Tôrres, 25 de setembro de 2015. 
a fim de fazer" não corresponde a uma atitude acrítica por parte do VNA. Por exemplo, ele contou que os homens Enawenê não consideravam importante englobar o universo feminino e que aquele aproveitava os momentos mais calmos para filmar as atividades das mulheres. De qualquer modo, tal como o coordenador do VNA, Tôrres também encontrou uma ansiedade dos Enawenê em registrarem tudo:

Eu tinha que filmar. Eles me acordavam três e meia da manhã, na cama, sacudindo a rede: “Tiago! Tiago! Filmar! Filmar! Tiago filma! Filma!” [...] Eu tenho horas e horas de filmagem que não dá para ver nada porque tinha que filmar. "Filma, filma, Tiago! Filma!” Mas rapidamente você entrava num transe porque [...] não tinha nenhum tipo de substância entorpecente, mas a sensação que dava era de você acordar às três e meia da manhã, pegar a câmara e bateria, você entra numa espécie de automatismo do cinegrafista, do profissional que sabe o que tem que fazer. Bateria, carregou e tal e aí você está ali e aqueles caras: "Uhuhuhuhuh". Você vai entrando num universo realmente que parece que não desenterra não! E os caras têm uma força, você vê criança carregando um pedaço de pau que eu não consigo mover! (Entrevista a Tiago Campos Tôrres, 25 de setembro de 2015).

O depoimento do cineasta ressoa com a ideia de ciné-transe, proposta por Jean Rouch. Segundo este autor, durante a rodagem, o realizador transforma-se através de uma cinépense que inclui um ciné-vois (um ver dentro dos limites da câmara e do microfone), um ciné-bonge (uma procura pelos melhores ângulos) e um ciné-monte (um cogitar sobre como os planos podem ser montados). Assim, através desta "ciné-attitude", "[...] the filmmaker can throw himself into a ritual, integrate himself with it, and follow it step-by-step [...] no longer invisible but participant in the ongoing event" (Rouch, 2003 [1973], p. 98). Nesse sentido, é possível advogar que esta entrega, esta ciné-attitude, transforma o ato de filmar num ritual que, por sua vez, é contaminado fenomenologicamente pelo ritual a ser registrado. Como Didi-Huberman (2012 [2004], p. 56, itálico no original) sublinha a propósito de quatro fotografias realizadas em segredo em Auschwitz durante o Holocausto, é importante ter em conta não só os aspetos formais, históricos, éticos e ontológicos da imagem, mas também a sua fenomenologia, "[...] tudo aquilo que fazia destas imagens um acontecimento (um processo, um trabalho, um corpo a corpo).” Por esta razão, como David MacDougall argumenta em Corporeal image (2006), o filme é constituído por corpos: o corpo do filme, os corpos no filme e o corpo do operador de câmara. Esta permeabilidade advém, como André Bazin (2005 [1967]) advogou, da “impureza” própria do cinema, isto é, da porosidade desta arte à influência de diversas agencialidades e outras artes, como a performance. De acordo com esta perspetiva, a qualidade de um documentário não está presente na suposta indexicalidade da câmara ou nas virtudes estéticas da imagem, mas na capacidade estético-política do cinema em capturar (dentro e fora de campo; à frente e atrás da câmara) uma determinada experiência da realidade.

Yaõkwá, um património ameaçado apresenta semelhanças e diferenças em relação ao primeiro filme, Yãkwá, o banquete dos espíritos. Em termos de estrutura narrativa, ambos os documentários seguem sequencialmente as fases mais importantes do ritual e acompanham 
estas com breves explicações mitológicas e cosmológicas. Curiosamente, a duração dos dois objetos filmicos também é similar. Em ambos os casos, o filme não se centra apenas num ou num número reduzido de personagens, apesar de no segundo trabalho aparecer com mais frequência o sobrinho de criação de Carelli porque "[...] a gente tem uma relação mais próxima, [ele] era uma das pessoas mais interessantes, mais abertas."35

Por outro lado, Yaõkwá, um património ameaçado é um filme diferente do trabalho anterior porque tem lugar num momento histórico totalmente distinto. Inicialmente, a diferença mais marcante é a presença de objetos ocidentais, como barcos a motor, camisas, bermudas, etc. que enunciam as transformações drásticas que decorreram nos quinze anos de intervalo entre os dois filmes. A este nível, a produção não indígena e indígena doVNA habitou-nos a ver a inclusão de elementos da modernidade pelos povos indígenas e a compreender que as culturas ameríndias não são caracterizadas por possuírem identidades estáticas, mas pelos modos como se transformam (Sahlins, 1997;Viveiros de Castro, 2002).

Porém, este ethos não invalida que as filmagens também sejam utilizadas pela comunidade para refletir sobre a sua situação colonial e futuro cultural, nomeadamente nas relações que pretendem estabelecer com a modernidade, e, portanto, como querem se transformar. Esta função está presente desde o primeiro filme do VNA, A festa da moça (Carelli, 1987), no qual uma comunidade Nambikwara, perante o visionamento na televisão da sua imagem demasiado ocidentializada, decidiu voltar a registrar um ritual sem as roupas não indígenas e recuperando os adornos e pinturas do seu povo. No caso dos Enawenê, um dos exemplos desta abordagem pode ser encontrado num curta-metragem de três minutos assinada por Paixão e Carelli, Peixe pequeno (2010). O filme não é legendado e, por isso, supõe-se que seja compreendido principalmente em termos simbólicos. Num acampamento dos Enawenê, os adultos constroem as estruturas cônicas que são colocadas nas barragens para capturar os peixes. Paralelamente, num plano-sequência dolorosamente longo, alguns meninos brigam por causa de uma garrafa de Coca-cola que possui uma forma similar às armações que os pais estão a produzir, mas que, neste caso, não captura peixes, mas o futuro dos Enawenê. Na sequência seguinte, os adultos estão a edificar a barragem no rio, enquanto os filhos disparam uns contra os outros com pistolas fabricadas com paus. Em três minutos, o filme questiona de uma forma pungente quem vai capturar e quem vai ser capturado: os peixes, os Enawenê ou a modernidade? 
Figura 6 - Peixe pequeno

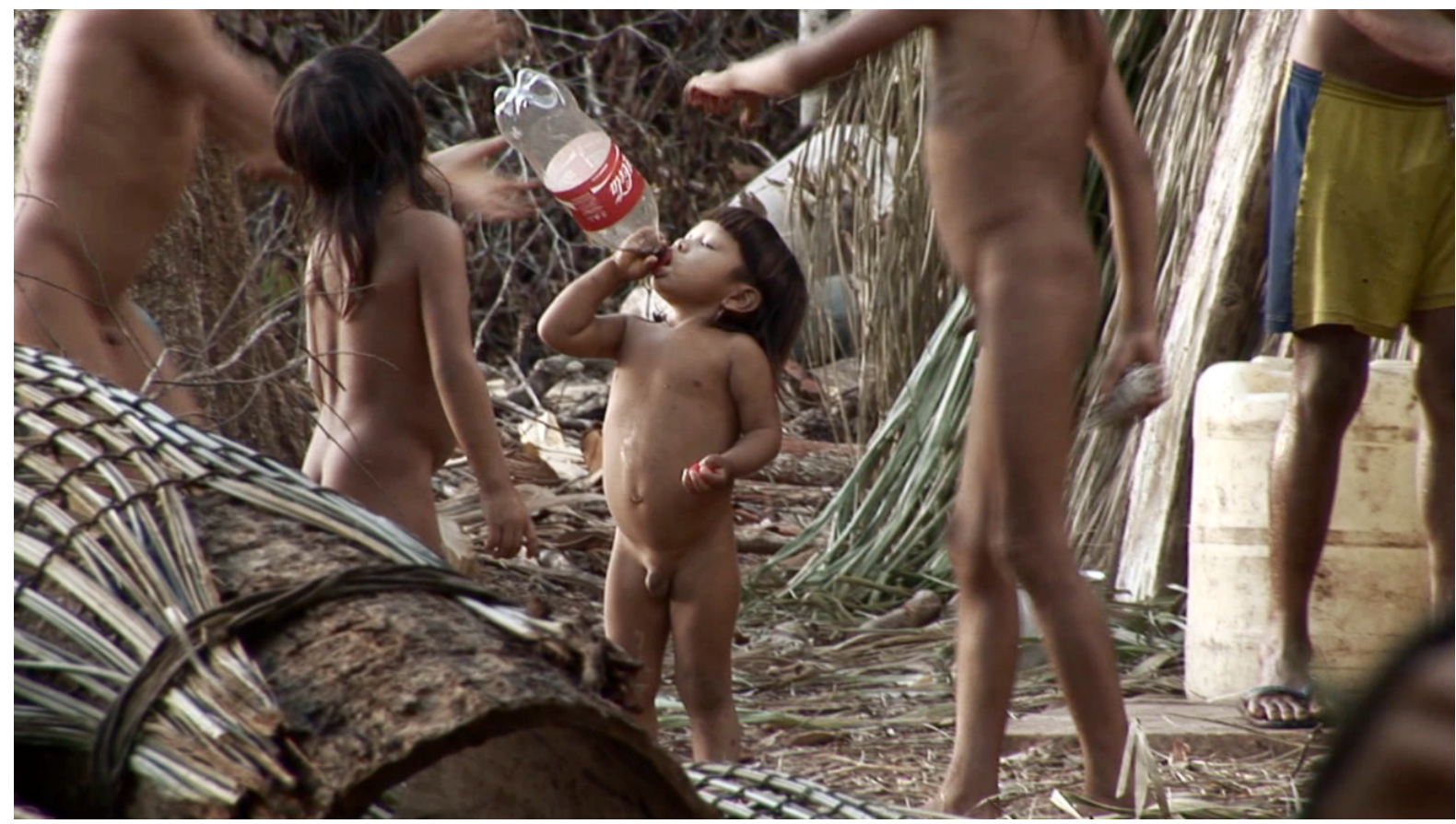

Fonte: Fotograma de Peixe Pequeno.

Contudo, a questão mais significativa para a reflexão sobre o futuro cultural dos Enawenê e a diferença mais drástica do filme Yaõkwa em relação à produção anterior é a ausência de peixes em 2009 causada pelas hidrelétricas, pelas alterações climáticas e por outras atividades com impacto ambiental. A meio do filme, durante o período em que os homens vão para as barragens construídas pelos Enawenê, estes começam a ficar preocupados com a ausência de peixe. Um deles comenta: "Se os brancos não ajudarem dessa vez, não teremos nada mesmo.” Perante esta situação, o Mestre de Cerimónias entra num barco e vai à cidade. De volta ao acampamento, distribui biscoitos pelos meninos e diz para a câmara: "Puxa, eu sou Mestre de Cerimônias, estou muito envergonhado com a falta de peixe! O funcionário me disse que chegam amanhã." No dia seguinte, num dos momentos mais frios e agoniantes do filme, alguns camiões chegam da cidade e despejam três toneladas de peixe de viveiro. ${ }^{36}$ Esta sequência não está legendada e é difícil compreender a reação dos Enawenê. Em alguns planos, eles parecem tristes, mas conformados, enquanto noutras imagens, eles aparentam estar alegres. É possível que tenham experienciado ambos os sentimentos. Por um lado, teriam peixe (ainda que relativamente pouco) para o Yaokwa de modo a saciar os Yakairiti. Por outro lado, os peixes não teriam a qualidade a que (os Enawenê e os espíritos) estavam habituados e eles encontravam-se dependentes da sociedade colonial. Segundo Nahum-Claudel (2018), os peixes de viveiro foram recebidos de uma forma muito negativa pelas mulheres na aldeia e o peixe capturado nas barragens foi mantido separado e utilizado nas trocas rituais de reciprocidade com os afins. Para colocar em perspetiva a quantidade entregue

36 Os peixes foram depositados por baixo de uma ponte que os Enawenê bloquearam várias vezes como forma de protesto e que se tornou num ponto importante de interação com os não indígenas (Nahum-Claudel, 2018). 
pelos camiões, a antropóloga menciona que, em 1994, segundo dados de um biólogo que trabalhou com a Opan, os Enawenê capturaram 18 toneladas de peixe fresco em três barragens, isto é, seis vezes mais. ${ }^{37} \mathrm{Em} 2010$ e 2011, os Enawenê compraram peixes com o dinheiro das contrapartidas obtidas da empresa hidrelétrica e, em 2012, o Iphan ofereceu sete toneladas de peixe como parte do plano de salvaguarda. Entretanto, demonstrando a sua capacidade de transformação cultural, alguns Enawenê iniciaram a criação de peixes em viveiros. De qualquer modo, os Enawenê questionam se as mortes que ocorreram recentemente na aldeia não estarão relacionadas com a insatisfação dos Yakairiti com as novas oferendas.

A inclusão no filme destas sequências foi criticada pela Superintendência do Iphan do Mato Grosso, que tinha contratado o VNA com a expectativa de que este utilizasse o seu arquivo para uma reconstrução idealizada do ritual. Tal como ocorreu noutros trabalhos do VNA com o Iphan, Carelli recusou recuar na sua abordagem: "Ah, porque eles achavam que eu não podia, que tinha que ter omitido o facto que não tinha peixe, e fazer de conta que você estava descrevendo o ritual como é. Falei: 'Porra! Mas se tem alguma coisa que interessa é chamar a atenção para o problema!"'38 Nesse sentido, apesar das potencialidades de autorrepresentação das práticas de "culturas com aspas", o património continua a privilegiar as identidades supostamente "autênticas" e "inalteradas". Tal como Manuela Carneiro da Cunha (2011, p. 286) menciona, "[s]ó às minorias se pede que exibam os traços culturais que se espera delas, e que são no mais das vezes estereótipos congelados". Assim, atualmente, os indígenas no Brasil encontramse enclausurados entre uma representação negativa colonial com séculos de existência e raízes profundas no imaginário nacional e uma representação romântica que seleciona apenas os aspetos positivos, muitas vezes do passado, e realiza traduções abusivas (por exemplo, a nível da cosmologia e ecologia) no sentido de criar uma imagem que nunca poderá corresponder à realidade. Contudo, é importante salientar que, apesar das críticas do Iphan, graças à obstinação dos Enawenê e do VNA, as sequências problemáticas à mentalidade do património foram mantidas no filme e que este processo, assim como as diversas cinematografias indígenas que emergiram nas duas últimas décadas, poderá suplantar o esquema dicotómico da representação indígena.

37 Leonardo Sette, coordenador de várias oficinas formação de cineastas indígenas, mencionou em entrevista que os povos indígenas tinham sempre curiosidade de ver as filmagens das outras comunidades para comparar técnicas de caça e que, quando viam as barragens dos Enawenê e a quantidade de peixe que eles capturavam, consideravam-nos como uma espécie de "super-heróis" (entrevista a Leonardo Sette, 25 de setembro de 2015).

38 Entrevista a Vincent Carelli, 16 de março de 2015. 
Figura 7 - Entrega de peixes em viveiro

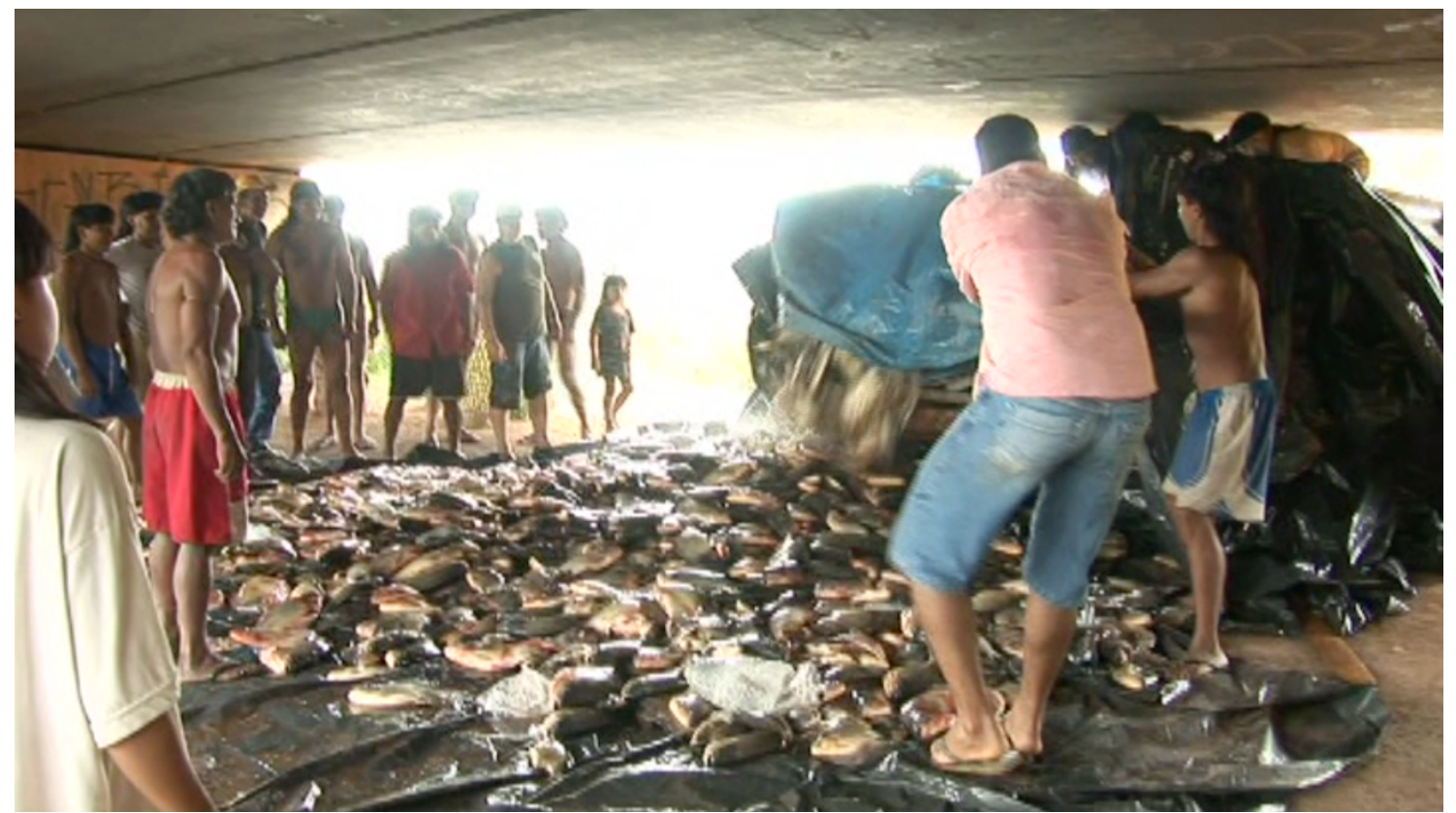

Fonte: Fotograma de entrega de peixes de viveiro em Yã̃kwá, um património ameaçado.

Outra limitação do património institucional que, contudo, não é possível aprofundar neste artigo, refere-se à incapacidade daquele em colocar em evidência equívocos ontológicos (Viveiros de Castro, 2004). Por exemplo, segundo Nahum-Claudel (2018) e Almeida (2015), o Yaokwa é melhor compreendido como um trabalho económico e de diplomacia social, política e cosmológica (com os espíritos Yakairiti) do que enquanto "bem cultural” ou “celebração". Nesse sentido, no contexto das cosmologias e ontologias ameríndias, é importante que o conceito de património seja expandido de modo a incluir a ação de humanos e extra-humanos e abolir as divisões da modernidade entre mente/ corpo e natureza/cultura (Harrison, 2003).

De qualquer modo, apesar das esperanças depositadas nas várias políticas de "cultura com aspas", este estudo de caso evidencia uma das principais limitações da apropriação destes instrumentos pelos povos indígenas: o poder simbólico do património é reduzido quando colocado em confronto com o poder do capital que avança vorazmente na fronteira amazónica. O banquete das "culturas" nada pode contra o banquete do capitalismo e este acabou com o banquete dos espíritos. Tal como decorreu noutros casos, como na barragem de Belo Monte (ver, por exemplo, Fainguelernt, 2013), as forças económicas utilizaram o dinheiro para corromper funcionários e instituições, promover a dissensão interna e entre comunidades e estabelecer situações de dependência (por exemplo, na necessidade de comprar combustível para os barcos a motor), desmantelando paulatinamente as estratégias de resistência. Como comenta um Enawenê:

Quando meu pai tinha a minha idade, tinha que se preocupar apenas com o Yaokwa, o Saloma, o Kateoko e o Lerohi, hoje tudo está diferente, temos que fazer tudo isso e ainda falar português, se preocupar com dinheiro e brigar muito para manter nossa terra bonita. Minha cabeça dói. Minha cabeça dói muito! (IPHAN, s.d., p. 197). 


\section{Considerações finais}

Os documentários Yâkwá, o banquete dos espíritos e Yaõkwá, um patrimônio ameaçado correspondem a dois momentos históricos diferentes, para os Enawenê e para as políticas de "culturas com aspas". No primeiro caso, os Enawenê reconheceram no cinema um mecanismo de patrimonialização não institucional que podia servir para arquivar informações sobre o ritual que se encontrava em perigo de se perder e enquanto instrumento de afirmação identitária que os mostra belos, fortes e numerosos. Na segunda situação, o filme faz parte de um processo de patrimonialização institucional a nível nacional e internacional de salvaguarda de um ritual que foi colocado em perigo pelos avanços do capitalismo. Nas duas conjunturas, os Enawenê demonstraram uma capacidade impressionante e célere de compreender os desafios que enfrentavam e os dispositivos a que podiam recorrer.

Contudo, este estudo de caso, assim como situações similares (por exemplo, a construção da barragem de Belo Monte), demonstra as limitações da "cultura com aspas" perante o poder dos interesses económicos. Quando estes estão presentes, as empresas e diversos agentes do Estado brasileiro desenvolvem estratégias e instrumentos lícitos e ilícitos para contornar as limitações legais, fomentar a dissensão interna dentro e entre comunidades, promover situações de dependência e esmorecer a luta. Tanto os planos de salvaguarda do Iphan, como o da Unesco, só têm poder para realizar, na linguagem daquela instituição, "propostas e recomendações" (IPHAN, s.d., p. 206), que ignoram os principais ataques ao modo de vida dos Enawenê e se centram em medidas de gestão dos problemas decorrentes do avanço do capital e em projetos de registo e de divulgação de conhecimentos tradicionais. Estas ações não seriam necessárias se os Enawenê tivessem controlo pleno sobre os recursos ambientais que têm influência sobre as suas terras. De facto, este estudo de caso faz lembrar uma experiência que a antropóloga Marcela Stockler Coelho de Souza teve com os Kîsêdjê no Parque Indígena do Xingu. Após aquela fazer uma apresentação sobre as principais políticas públicas e privadas relacionadas com o património imaterial (incluindo Iphan, Pontos de Cultura do Ministério da Cultura, editais da Petrobrás, etc.), um representante indígena respondeu "pensativa e sobriamente": “[...] eu só queria que parassem de desmatar a terra e poluir o rio. Da nossa cultura a gente mesmo pode cuidar" (Souza, 2010, p. 98). Parafraseando o comentário desta liderança, se estes direitos fossem garantidos, os Enawenê saberiam como tratar da sua cultura e continuar o Yaokwa.

Em suma, a explosão do banquete de "culturas" nunca poderá fazer frente ao banquete do capitalismo enquanto a soberania dos povos indígenas sobre os seus recursos e cosmologias não for expandida e respeitada.

\section{Referências}

ALMEIDA, Juliana. Alta tensão na floresta: os Enawene-Nawe e o Complexo Hidrelétrico Juruena. In: LIMA, Artema; FANZERES, Andreia; ALMEIDA, Juliana (Org.). Jeitos de fazer: experiências metodológicas para elaboração de planos de gestão territorial em terras indígenas. Campinas: Editora Curt Nimendaju, 2011.p.27-32. 
ALMEIDA, Juliana. Enawene-Nawe Wixo: diferença e convivialidade na gestão sociopolítica do cosmos. 2015. Tese (Mestrado) - Universidade Federal do Amazonas, Manaus, 2015.

BAZIN, André. What is cinema? v. 1. Berkeley/Los Angeles: University of California Press, 2005 [1967].

BRIGARD, Emilie de. The history of ethnographic film. In: HOCKINGS, Paul (Org). Principles of visual anthropology. Berlin: Mouton de Gruyter, 2003 [1974]. p. 13-43.

CHOAY, Françoise. Alegoria do património. Lisboa: Edições 70, 2010 [1982].

CUNHA, Manuela Carneiro da. Cultura com aspas. São Paulo: Cosac Naify, 2009.

CUNHA, Manuela. Índios como tema do pensamento social no Brasil. In: BOTELHO, André; SCHWARCZ, Lilia Moritz. Agenda brasileira: temas de uma sociedade em mudança. São Paulo: Companhia das Letras, 2011. p. 278-291.

DERRIDA, Jacques. Archive fever: a freudian impression. Diacritics, v. 25, n. 2, p. 9-63, 1995.

DIDI-HUBERMAN, Georges. Imagens apesar de tudo. Lisboa: KKYM, 2012 [2004].

DURINGTON, Matthew; RUBY, Jay. Ethnographic film. In: BANKS, Marcus; RUBY, Jay (Orgs). Made to be seen. Perspectives on the history of visual anthropology. Chicago/London: The University of Chicago Press, 2011. p. 190-208.

EDWARDS, Elizabeth. Tracing photography. In: BANKS, Marcus; RUBY, Jay (Orgs). Made to be seen. Perspectives on the history of visual anthropology. Chicago/London:The University of Chicago Press, 2011. p. 159-189.

FAINGUELERNT, Maíra Borges. Belo Monte. O estado democrático de direito em questão. Rio de Janeiro: Apicuri, 2013.

GALLOIS, Dominique Tilkin; CARELLI,Vincent.Vídeo e diálogo cultural - experiência do Projeto Vídeo nas Aldeias. Horizontes Antropológicos, n. 2, p. 61-72, 1995.

GALLOIS, Dominique Tilkin; CARELLI,Vincent. 'Vídeo nas Aldeias': a experiência Waiãpi. Cadernos de Campo, n. 2, p. 25-36, 1992.

GALVÃO, Maryanne. Pequenas centrais hidrelétricas, comunidades indígenas e espoliação: o projeto Juruena e os Enawene Nawe no Mato Grosso. 2016. Tese (Doutorado) - Universidade Estadual de Campinas, Campinas, 2016.

GINSBUR G, Fae. Aboriginal media and the Australian imaginary. Public Culture, v. 5, n. 3, p. 557-578, 1993.

GORDON, Cesar. Em nome do belo: o valor das coisas xikrin-mebêngôkre. In: SILVA; Fabíola Andreá; GORDON, Cesar (Orgs). Xikrin. Uma coleção etnográfica. São Paulo: Edusp, 2011. p. 207-262.

HARRISON, Rodney. Heritage: critical approaches. Oxon/New York: Routledge, 2013.

HENLEY, Paul. Le récit dans le film ethnographique. L'Homme. n. 198-199, p. 131-157, 2011.

HENLEY, Paul. The adventure of the real: Jean Rouch and the Craft of Ethnographic Cinema. Chicago/London: The University of Chicago Press, 2010.

Iphan - Instituto do Patrimônio Histórico Brasileiro.. Dossiê de Registro do Yaõkwa como Patrimônio Imaterial do Brasil. Instituto do Patrimônio Histórico e Artístico Nacional, s.d.

JAKUBASZKO, Andrea. Imagens da alteridade: um estudo da experiência histórica dos Enawene Nawe. 2003. Tese (Mestrado) - Pontificia Universidade Católica de São Paulo, São Paulo, 2003.

MACDOUGALL, David. The corporeal image: film, ethnography, and the senses. Princeton: Princeton University Press, 2006.

MACDOUGALL, David. Transcultural cinema. New Jersey: Princeton University Press, 1998.

MEAD, Margaret. Visual anthropology in a discipline of words. In: HOCKINGS, Paul (Org). Principles of visual anthropology. Berlin: Mouton de Gruyter, 2003 [1974]. p. 3-10.

NAHUM-CLAUDEL, Chloe. Vital diplomacy: the ritual everyday on a dammed river in Amazonia. New York/ Oxford: Bergahn, 2018. 
OVERING, Joana. A estética de produção: o senso de comunidade entre os Cubeo e os Piaroa. Revista de Antropologia, v. 34, p. 7-33, 1991.

OVERING, Joana; PASSES, Alan. The anthropology of love and anger: the aesthetics of conviviality in native Amazonia. London/New York: Routledge, 2000.

PINNEY, Christopher. Photography and anthropology. London: Reaktion Books, 2011.

RAMOS, Alcida Rita. Indigenism: ethnic politics in Brazil. Madison:The University of Wisconsin Press, 1998.

RODGERS, Ana Paula Lima. O ferro e as flautas. Regimes de captura e perecibilidade no Iyaõkwa Enawene Nawe. 2014. Tese (Doutorado) - Universidade Federal do Rio de Janeiro, Rio de Janeiro, 2014.

ROUCH, Jean. On the vicissitudes of the self: the possessed dancer, the magician, the sorcerer, the filmmaker, and the ethnographer. In: FELD, Steven (Org). Ciné - ethnography. Minneapolis: University of Minnesota Press, 2003 [1973]. p. 87-101.

SAHLINS, Marshall. O 'pessimismo sentimental' e a experiência etnográfica: por que a cultura não é um "objeto" em via de extinção (Parte II).” Mana, v. 3, n. 2, p. 103-150, 1997.

SANTOS, Gilton Mendes dos. Da cultura à natureza. Um estudo do cosmos e da ecologia dos Enawene-Nawe. 2006. Tese (Doutorado) - Universidade de São Paulo, São Paulo, 2006.

SILVA, Márcio Ferreira da. Tempo e espaço entre os Enawene Nawe. Revista de Antropologia, São Paulo, USP, v. 41, n. 2, p. 21-52, 1998.

SMITH, Laurajane. Uses of heritage. Oxon: Routledge, 2006.

SOUZA, Marcela Coelho de. A vida material das coisas intangíveis. In: LIMA, Edilene Coffaci; SOUZA, Marcela Coelho de (Orgs). Conhecimento e cultura: práticas de transformação no mundo indígena. Brasília: Athalaia Gráfica e Editora, 2010. p. 97-118.

TURNER, Terence. Representation, politics, and cultural imagination in indigenous video: general points and Kayapo examples. In: GINSBURG, Faye; ABU-LUGHOD, LILA; LARKIN, Brian (Orgs). Media worlds: anthropology on New Terrain. Berkeley/Los Angeles/London: University of California Press, 2002. p. 75-89.

VALADÃO,Virgínia. O processo de trabalho do vídeo Yakwã: o banquete dos espíritos In: ECKERT, Cornelia; MONTE-MOR, P. (Orgs). Imagem em foco: novas perspectivas em antropologia. Porto Alegre: UFRS, 1999. p. 161-175.

VIVEIROS DE CASTRO, Eduardo. Perspectival anthropology and the method of controlled equivocation. Tipiti: Journal of the Society for the Anthropology of Lowland South America, v. 2, n. 1, p. 3-20, 2004.

VIVEIROS DE CASTRO, Eduardo. A inconstância da alma selvagem e outros ensaios de Antropologia. São Paulo: Cosac Naify, 2002.

\section{Filmografia}

A Festa da Moça. Direção:Vincent Carelli. Produção: CTI. 18 minutos. Brasil, 1987.

ANTROPOFAGIA VISUAL. Direção:Vincent Carelli. Produção: CTI. 17 minutos. Brasil, 1995.

AVAETÉ, a Semente da Vingança. Direção: Zelito Viana. Produção: Embrafilme, Mapa Filmes. 110 minutos. Brasil/Alemanha de Leste, 1985.

DANCES WITH WOLVES. Direção: Kevin Costner. Produção: Tig Productions, Majestic Films International, Allied Filmmakers. 181 minutos. EUA/RU, 1990.

GERONIMO: An american legend. Direção: Walter Hill. Produção: Columbia Pictures Corporation. 115 minutos. EUA, 1993.

LES MAÎTRES FOUS. Direção: Jean Rouch. Produção: Les Films de la Pléiade. 36 minutos. França, 1955. 
O ESPÍRITO DA TV. Direção:Vincent Carelli. Produção: CTI. 18 minutos. Brasil, 1990.

PEIXE PEQUENO. Direção:Altair Paixão,Vincent Carelli. Produção:Vídeo nas Aldeias. 3 minutos. Brasil, 2010. WAPTÉ MNHÕNÕ, Iniciação do Jovem Xavante. Direção: Divino Tserewahú. Produção: CTI/Vídeo nas Aldeias. 56 minutos. Brasil, 1999.

YÃKWÁ, O Banquete dos Espíritos. Direção:Virgínia Valadão. Produção: Centro de Trabalho Indigenista. 54 minutos. Brasil, 1995.

YAÕKWÁ, Um Património Ameaçado. Direção:Vincent Carelli e Fausto Campoli. Produção: IPHAN/OPAN/ Vídeo nas Aldeias. 62 minutos. Brasil, 2009.

\title{
The Banquets of Yaokwa: Potentials and Limits of Cinema and Heritage Among the Enawenê-nawê
}

\begin{abstract}
The article examines the use of cinema in non-institutional and institutional heritage processes, of the Yaokwa ritual from the Enawenê-nawê people at two different historical moments using statements from indigenous filmmakers and anthropologists, film analysis and the Amerindian bibliography. The works were produced by the project "Vídeo nas Aldeias" which, since the 1980s, has been developing collaborative work with indigenous communities in the audiovisual area.The first documentary was made in the context of internal reflection about the relationship to be established with colonial society. The second film was produced fifteen years later as part of the institutional heritage process of the Yaokwa ritual that aimed to alert to the environmental challenges that many capitalist enterprises posed to the maintenance of the Enawenê-nawê way of life.
\end{abstract}

Keywords: Enawenê-nawê.Yaokwa. Heritage. Indigenous cinema. "Vídeos nas Aldeias".

\section{Los banquetes de Yaokwa: potencialidades y límites del cine y del patrimonio entre los Enawenê-nawê}

\section{Resumen}

El artículo analiza la utilización del cine en procesos de patrimonialización no institucional e institucional del ritual Yaokwa, perteneciente al pueblo Enawenê-nawê, en dos momentos históricos distintos, recurriendo a testimonios de cineastas y antropólogos indigenistas, al análisis filmico y a la bibliografia amerindia. Las obras fueron producidas por el proyecto "Vídeo nas Aldeias", que desarrolla, desde la década de los ochenta, un trabajo colaborativo con comunidades indígenas en el área de producción audiovisual. El primer documental fue realizado en un contexto de reflexión interna sobre la relación a establecer con la sociedad colonial. La segunda película fue producida quince años después, como parte del proceso de patrimonialización institucional del ritual Yaokwa, que tenía como objetivo advertir sobre los desafíos ambientales que varios emprendimientos capitalistas disponían al mantenimiento del modo de vida de los Enawenê-nawê.

Palabras clave: Enawenê-nawê.Yaokwa. Patrimonio. Cine indígena.Vídeo en las Aldeas. 